\title{
Trade and foreign direct investment: Evidence from South East European countries and new European Union member states ${ }^{* 1}$
}

\author{
Bardhyl Dauti ${ }^{2}$
}

\begin{abstract}
The goal of this research is to provide an empirical assessment of the complementarity or substituting relationship between Trade and FDI in a link to country characteristics, using bilateral level data between FDI and trade for the period $1994-2010$. In the research, an augmented gravity model has been used to test the relationship between Trade (both export and import), FDI stock and country characteristics between OECD-20 countries and SEE-5 and EU-NMS-10 countries. The empirical model considers how the relationship between FDI and Trade determine whether type of FDI into SEE-5 and EU-NMS-10 from core OECD-20 countries, is vertical or horizontal. With regard to the relationship between exports and FDI, the findings of the research showed mixed evidence, thus supporting vertical FDI for EU-NMS-10 countries, and horizontal FDI for SEE-5 countries. On the other hand, based on the relationship between imports and FDI, the results of the research supported vertical FDI for both EU-NMS-10 and SEE-5 group of countries. The basic conclusion is that the research provides an empirical evidence on the mixed nature of FDI into the host SEE-5 and EU-NMS-10 countries, supporting both complementary and substituting relationship between trade and FDI in the host countries.
\end{abstract}

Key words: foreign direct investment, trade, complements, substitutes, gravity model

JEL classification: F12, F14, F21, F23

\footnotetext{
* Received: 14-02-2016; accepted: 17-06-2016

1 For a fruitful discussion and useful comments made on the presentation of this paper at the PhD conference organized by the Faculty of Economics, University of Ljubljana (FEUL) on June 11, 2014, where the topic of this paper was presented, the author would like to express his gratitude to Professors: Jože P. Damijan, Črt Kostevc, Matija Rojec and Anže Burger, as well as to two anonymous referees of the Zbornik radova Ekonomskog fakulteta u Rijeci: časopis za ekonomsku teoriju i praksu/Proceedings of Rijeka Faculty of Economics: Journal of Economics and Business.

2 Assistant Professor, Faculty of Economics, University of Tetovo, Ilindenska road, 1200 Tetovo, Macedonia. Scientific affiliation: macroeconomics, international trade, modern economic systems.E-mail: bardhyl.dauti@unite.edu.mk.
} 


\section{Introduction}

The increased rivalry and competition in international markets have led to significant changes in the pattern of exports and FDI during the last two decades. In this regard, world total trade in goods (export flow of goods), which amounted to 6.7 trillions of US dollars in 1990, had increased almost six times in 2013 to 37.6 trillions of US dollars (UNCTAD, 2013). The evolution of Foreign Direct Investment (FDI) also follows intensive increasing patterns as well. The world level of the stock of inward FDI was twelve times higher in 2013 (25.4 trillions of US dollars) than in 1990 (2.0 trillions of US dollars) (UNCTAD, 2013).

The relationship between FDI and exports has received extensive attention in recent empirical evidence. On theoretical grounds, predictions concerning the relationship between FDI and exports crucially depend on whether FDI is horizontal or vertical. Theories of horizontal FDI as in Markunsen (1984), which are based on production of homogenous goods in multiple countries predict a negative relationship between FDI and exports, thus FDI and exports may be considered as substitutes for each other, whereas theories on vertical FDI as in Helpman (1984), which are based on a geographically fragmented production process by stages predict a positive relationship between FDI and exports, thus FDI and exports may be considered as complements to each other. Linking to national characteristics, horizontal FDI operates under the conditions of large absolute market size, similar relative factor endowments, moderate and high trade costs and trade barriers, high tariff barriers and the existence of large economies of scale at firm level and low economies of scale at plant level (Shatz and Venables, 2000). On the other hand, vertical FDI operates under conditions of small absolute market size, different relative factor endowments, low trade costs and trade barriers and low tariff barriers. Trade costs, on the other hand, have a negative influence on the location of vertical FDI (Shatz and Venables, 2000), making for example Central and Eastern European countries interesting regarding this sort of FDI from Western industrialized countries (Markusen et al., 1996).

Drawing on a theoretical framework developed by Markusen et al. (1996), the main aim of this paper is to provide empirical evidence concerning the relationship between FDI and trade (exports and imports), in the European region, based on country characteristics. The focus of this paper is to investigate empirically the relationship between bilateral FDI stocks between countries and trade (at both export and import level) using bilateral data for the 20 member countries of the Organization for Economic Cooperation and Development (OECD-20) and 5 South East European Countries (SEE-5) and 10 new member states of European Union (EU-NMS-10) countries over a period of 17 years. The research will test the primary hypothesis: Do inward FDI have a significant and positive effect on trade, suggesting that exportplatform FDI may be important for the SEE-5 and EU-NMS-10 countries. The framework of the research will link these country characteristics to the relationship 
between FDI and trade to generate the hypotheses: It is expected that FDI from OECD-20 to SEE-5 and EU-NMS-10, will have an effect on increasing the exports and imports from SEEC-5 and EU-NMS-10 to OECD-20. A negative relationship between FDI and trade suggests the domination of horizontal FDI; hence, FDI and trade are substitutes. In this case horizontal FDI should decrease bilateral exports and imports. Alternatively, a positive relationship between FDI and trade, favors the domination of vertical FDI, hence FDI and trade are complements. Vertical FDI should increase imports of intermediates and exports of final goods. In line with Markusen's et al. (1998) theoretical framework concerning the relationship between FDI and Trade, we consider the role of country characteristics as well as trade costs in explaining FDI and Trade pattern among SEE-5 and EU-NMS-10 countries.

The findings of the research suggest that inward FDI stock is positively related to import flows for both group of countries (SEE-5 and EU-NMS-10), implying that FDI and imports are complements for both group of countries and negatively (positively) related to export flows for SEE-5 (EU-NMS-10) countries, implying that FDI and exports are substitute (complements) for SEE-5 (EU-NMS-10) countries. This paper by applying the standard methodology of the gravity model to the dataset of South East European countries and New European Member states contributes to the literature of relationship between FDI and trade (at both export and import level) in transition countries.

The paper is organized as follows. The next section proceeds with a presentation of empirical studies concerning the relationship between FDI, country characteristics and exports, using aggregate level data. Section three describes the methodology and method of analysis. Section four presents the data description. Section five presents results obtained by estimating the empirical model framework. The last section concludes the research.

\section{Literature review}

There are two groups of empirical studies on vertical and horizontal FDI. The first tried to explain the total amount of FDI, stock or flow level between two particular countries (Carr et al., 2001; Markusen and Maskus, 2002). The second group of studies estimated the export share of total sales of the affiliate companies, with respect to relevant country characteristics (Blonigen et al., 2003).

Brainard (1997) found strong empirical support for horizontal FDI between similar countries. She showed that the share of local sale by affiliates is increasing in trade costs and trade barriers. In addition, the sale of foreign affiliates of US firms is higher in countries with higher transport costs and tariffs. Secondly, the US multinationals serve the foreign market more through FDI and less through exports, 
the latter being the scale of corporate operations relative to the scale of production. Here scale economies in headquarters are stronger relative to scale economies in production, which also supports horizontal FDI. These results confirm the main characteristics of horizontal FDI to be used as market access in remote markets.

Brainard (1997a), by using firm level data from the Annual Survey of US Direct Investment Abroad at a bilateral level between US and 90 partner countries, and yielding approximately 70,000 firm country-time observations, found that labor in the United States does compete at the margins with labor abroad via multinational production. Thus there is a vertical separation of activities to take advantage of wage differentials, with affiliates in developing countries performing the activities that are most sensitive to labor costs. Considering factor price endowments, the results confirmed that parent employment responds very little to variations in affiliate wages, and therefore affiliate employment actually expands when wage in countries at different level of development fall.

Brainard (1997b), by using firm-level panel of foreign manufacturing affiliates owned by US multinationals and summing up to approximately 60,000 firm-countryyear observations, for the period between 1983 and 1992, found evidence that affiliate activities in developing countries appear to be complementary for affiliate activities in industrialized countries. The results of the paper suggest that multinationals with affiliates in countries at different stages of development decompose production across borders into complementary stages that differ by skill intensity.

Blonigen et al. (2003), by using pool inward and outward U.S affiliate sales data from 1986 through 1994, U.S. samples with alternative proxies for key variables, as well as a sample of FDI activity across OECD countries, found that the key variables identifying vertical MNE motivations have the expected sign and are statistically significant. The authors also provided evidence that the negative relationship between FDI activity and dissimilarity in skilled - labour abundance is also found using data that include a wider variety of parent and host countries, including data for the OECD. The authors did not find support in any of these data sets for rejecting the horizontal model of FDI.

Ekholm et al., (2003), by using a panel of cross-country observations over the period 1986-1994, from the U.S. Department of Commerce found strong evidence of the presence of direct investment between countries both in size and relative endowments. However, the results of the study provided strong support for the Knowledge-Capital (KK) model, with no significant distinction from the horizontal model of FDI. A principal message of the study is that a vertical model of FDI is a poor characterization of the overall pattern of world FDI activity, a finding consistent with the results in Brainard (1997).

Head and Ries (HR, 2003) by using data on 1070 large Japanese firms in 1989 show that when a host country offers no cost advantage the investors abroad are 
more productive than exporters. Allowing for low-cost foreign production reverses this pattern as low productivity firms are most attracted to relocate production to a low-cost foreign country. Evidence provided in these studies is not general in the sense that so far only the patterns of production of MNCs from developed countries have been studied. Among developed countries a horizontal type of FDI is most likely to occur. HMY emphasize some of the determinants of horizontal FDI (total factor productivity, fixed costs, and trade costs).

Helpman, Melitz and Yeaple (HMY, 2004) develop a model of the firm's choice between exports and horizontal FDI. They are the first to consider the heterogeneity in productivity (after controlling for capital intensity) as a key factor in a firm's decision whether to supply only domestic markets or to supply also foreign markets, either through exports or FDI. Firms decide for these three options depending on their productivity. The least productive firms may choose to exit, more productive firms to serve only domestic markets, relatively more productive to serve domestic markets through local production and foreign markets through exports, and the most productive firms engage in FDI.

Martinez, Benoga and Robles (2012), by using a panel of cross-country data on the EU-19 host countries of FDI and outer EU-5 source countries of FDI over the period 1995 - 2006 found that EU commercial integration and FDI reinforce each other, thus being complementary. Also, the findings of irrelevant cost differentials between countries suggest that in the EU the FDI pattern follows a horizontal strategy rather than vertical one.

\section{Methodology and method of analysis}

In this paper, we test the relationship between FDI and trade (exports and imports) by including SEE-5 and EU-NMS-10 countries as exporting (partner) countries and host countries of $\mathrm{FDI}^{3}$ and OECD countries as importing (reporting) countries and source countries of $\mathrm{FDI}^{4}$. Two different equations are estimated, one for SEE-5 and EU-NMS-10 export flows to OECD-20 and the other one for SEE-5 and

\footnotetext{
3 The above countries are selected for the purpose of our research. We keep out from our analysis some other transition countries, as host countries of FDI and exporting (partner) countries, because circumstances throughout much of the period considered in this research make them special cases that would need country-specific explanations. Among the SEE countries, Kosovo and Montenegro are not included in the sample of host countries of FDI and exporting (reporting) countries, because there is no data available or at best, it is available only for few years.

4 The selected source OECD-20 countries, which are considered also as importing (reporting) countries, are the key suppliers of FDI for SEE-5 countries and EU-NMS-10 countries. All of these countries had trade (export and import) and foreign direct investment flows among them The combined level of FDI outward stock in 2015 of OECD-20 countries to EU-NMS-10 and SEE-5 countries accounted for 80 per cent (OECD, 2013). Also, extending the data to other source countries of FDI and importing (reporting) countries, would result in a high proportion of zeros or missing values.
} 
EU-NMS-10 import flows from OECD-20. The reduced form gravity equation of related choice variables is given below:

$$
\begin{aligned}
\ln X_{j i, t}= & \mu_{t}+\beta_{0} \ln F D I_{i j, t-1}+\beta_{1} \ln \left|G D P_{i, t-1}-G D P_{j, t-1}\right|+\beta_{2} \ln \mid G D P c_{i, t-1}- \\
& -G D P c_{j, t-1} \mid+\beta_{3} \ln A_{i j}+\beta_{4} \ln E_{j t}+\varphi+\delta+\theta+\varepsilon_{i j, t}
\end{aligned}
$$

Where $\ln X_{j i, t}$ stands for exports (or imports) flows from country $j$ (SEE-5 and EU-NMS-10) to country $i$ (OECD-20) in year $t$. $\ln F D I_{i, t, t-1}$ is inward stock of FDI in host country $j$ from source country $i$ in year $t$. The $\ln F D I$ variable is lagged by one period $(n=1)$ in order to allow the foreign direct investment the grace period before is starts at impacting host country's exports (imports). $\ln \left|G D P_{i, t-1}-G D P_{j, t-1}\right|$ and $\ln \left|G D P c_{i, t-1}-G D P c_{j, t-1}\right|$ is the absolute difference between countries $i$ and $j$ GDP and GDP per capita. Both variables are used in absolute difference terms, in order to avoid the problem of negative values ${ }^{5}$. Both variables are lagged by one period in order to avoid the problem of endogeneity between gross domestic product and exports as the dependent variable. $A_{i j}$ captures all the time invariant factors, such as distance, common land border, common language etc, while $\ln E_{j t}$ denote the country's $j$ explanatory variables. $\mu_{t}$ is a time dummy, $\varphi$ is host country dummy, $\delta$ is source country dummy and $\theta$ is pair country dummy. The $\varepsilon_{i j, t}$ is the usual standard error.

\subsection{Empirical model}

For estimation purposes, we extend the reduced form equation for estimating bilateral relationship between Trade and $\mathrm{FDI}^{6}$. The estimated gravity equation is the following:

$$
\begin{aligned}
\ln X_{j i, t}= & \mu_{t}+\beta_{0} \ln F D I_{i j, t-1}+\beta_{1} \ln \left|G D P_{i, t-1}-G D P_{j, t-1}\right|+\beta_{2} \ln \mid G D P c_{i, t-1}- \\
& -G D P c_{j, t-1} \mid+\beta_{3} \ln D_{i j}+\beta_{4} C O N T I G+\beta_{5} S M C T R Y+\beta_{6} \ln O P_{j, t-1}+ \\
& +\beta_{7} \ln \left|S K I L L_{i, t-1}-S K I L L_{j, t-1}\right|+\beta_{8} \ln \left|C A P_{i, t-1}-C A P_{j, t-1}\right|+ \\
& +\beta_{9} \ln F D I_{i j, t-1} \times S E E+\beta_{10} S E E+\varphi+\delta+\theta+\varepsilon_{i j, t}
\end{aligned}
$$

The dependent variable in the model is $\ln X_{j i, t}$ denoting the bilateral exports (imports) in goods from exporting (importing) country $j$ (SEE-5 and EU-NMS-10) to importing (exporting) country $i$ (OECD-20), in year $t$, calculated in millions

\footnotetext{
5 Moreover, some of the developed OECD countries; i.e. Portugal, have lower GDP and GDP per capita levels recorded during the observed period, 1994 - 2010, in comparison to EU-NMS-10 countries, i.e. Poland. The same logic applies with SEE-5 countries. Turkey, for example as a part of the sample of OECD countries has lower GDP per capita level than Croatia. Hence, by considering the absolute difference of GDP and GDP per capita between developed OECD countries and EU-NMS-10 and SEE-5 countries, we take care of negative observations in the matrix of the respective variables of absolute differences of GDP and GDP per capita.

${ }^{6}$ Descriptive statistics of the variables employed in the model is given in appendix A1. Correlation matrix of the variables used in the model is given in appendix A2 and A3. Description of the variables used in the empirical model is given in appendix A4.
} 
of US dollars. We include $\ln F D I_{i j, t-1}$ as an explanatory variable, on its own, denoting the stock of bilateral FDI into SEE-5 and EU-NMS-10, originated from OECD $-20^{7}$. This variable is included in the model to allow for factors outside this model that may affect the relationship between trade and FDI. The variable $\ln \left|G D P_{i, t-1}-G D P_{j, t-1}\right|$, denoting the absolute difference of GDP also reflect the absolute differences between export supply and import demand between trading partners. According to standard trade theory, we would expect that an increase in the difference in GDP between partner countries will reduce the trade volume between countries, since trade is expected to maximize when countries are of equal size (Helpman and Krugman, 1986). However, according to standard gravity model applied in trade studies, we expect positive impact of the absolute difference of GDP between trading partners on the size of bilateral trade (export and import) flow. The variable $\ln \left|G D P c_{i, t-1}-G D P c_{j, t-1}\right|$, denoting absolute difference of GDP per capita, on the other hand, reflect the comparative cost differences and combined similarities in tastes between trading countries (Frankel et al., 1995). The absolute difference of GDP per capita variable is included in the model in line with the perceptions of the theoretical foundations of Heckscher-Ohlin theory and Linder's theory on international trade (Frankel et al., 1995). However, none of the both theories can predict the relation between trade (export and import) and GDP per capita levels found empirically. Based on the concept of cost comparative differences and combined tastes between countries, it is expected that high income OECD countries will trade more with relatively low income EU-NMS-10 and SEE-5 countries. ${ }^{8}$ To capture the trade costs, the model will include the distance variable $\ln D_{j t}$ to reflect natural barriers (Carr et al., 2001). The variable of distance $\ln \mathrm{D}_{\mathrm{ijt}}$ represents the gravity factor. Distance between source and host country is expected to have a negative effect on the size of trade flows, due to costly adoptions of goods to local preferences (Johnson, 2006) and high transportation costs (Bevan and Estrin, 2004; Resmini, 2000). The dummy variables of COUNTIG and SMCTRY are the standard gravity variables. These variables denote the alternative estimates of trade costs. The variable of openness denoted by $\operatorname{lnOP}_{\mathrm{jt}}$ will be included in the model to account for the openness level of the SEE and EU-NMS countries (Bos and De Laar, 2004). This variable is measured by the sum of exports and imports in goods and services over GDP. The variable of openness is used to capture the de

\footnotetext{
7 The use of FDI stock variable instead of its alternative of FDI flow has two key advantages: First, the stock variable avoids the problem of multicollinearity between trade and investment flows, given that such flows are simultaneously affected by the same economic variables. Second, the use of FDI stock is a more correct approach, since the lagged FDI flows do not have impact on trade. Hence, the use of FDI stock variable is moreover able to capture the time lag effects which are not the case with FDI flows.

${ }^{8}$ Moreover, considering the theoretical considerations on international trade of Helpman and Krugman (1985) Heckscher-Ohlin and Linder's preference-based theory (1953); the effects of country characteristics, denoted by GDP and GDP per capita on trade, do not accord well by including the respective levels of GDP and GDP per capita for both trading partners, but, rather by considering the absolute differences of GDP and GDP per capita between trading countries.
} 
jure liberalization of trade and foreign exchange transactions. The fewer restrictions an importing country imposes on trade the higher will be trade flow from an exporting country. Therefore, a positive relationship between trade openness and trade flow is expected. To capture the effect of the difference in relative factor endowments on export and import flow between source and host countries, we have included in the model the variable $\ln \left|S K I L L_{i, t-1}-S K I L L_{j, t-1}\right|$, denoting the absolute difference in the relative skill endowments between country $i$ and $j$, and $\ln \left|C A P_{i, t-1}-C A P_{j, t-1}\right|$ variable, denoting the absolute difference in the relative capital endowments between country $i$ and $j$. According to standard trade theory, it is expected that an increase in differences in relative endowments will increase trade flow (Helpman and Krugman, 1986). Hence it is expected that the coefficient of skill and capital endowment to be significantly and positively related to bilateral trade. The variables of absolute difference of GDP, GDP per capita, skill endowment and capital endowment are used in the model to represent the country characteristics of the trading partners. The interaction between FDI and SEE dummy, $\ln F D I_{i j, t-1} \times$ SEE, is included in the model to estimate the difference in the effects of FDI on trade between the two groups of host countries. SEE dummy variable is constitutive term.

\subsection{Econometric framework}

In the analysis, static panel models and dynamic panel models are considered. We start with robust fixed effects (FE) estimates. Post estimations (see Appendix A5 and A6), we subjected our conventional FE model to a series of diagnostic tests. In this regard, the diagnostic testing procedures have suggested selecting the robust fixed effect estimates with year dummies as most appropriate estimates for interpreting the results. However, the usual problem with estimating trade flows, using gravity equation, is the multilateral resistance terms (MRTs). To proxy MRTs, following Rose and Wincop, (2001); Feenstra, (2004); Baldwin and Taglioni, (2006) we use country fixed effects for exporting countries and importing countries, time fixed effects and country-pair fixed effects. ${ }^{9}$ Moreover, the models with time and country fixed effects are employed to control for common external shocks and unobserved country-fixed effects. It has been frequently argued that the static panel data approach may lead to biased parameter estimates as it does not take into account the potential endogeneity of explanatory variables.

The standard static panel model does not correct the biases due to the presence of the lagged dependent variable. To check for the robustness of our results obtained using the static panel data techniques, we run dynamic panel data regression using Arrellano-Bover/Blundell/Bond estimation procedure (Arrellano and Bover, 1995;

\footnotetext{
9 An advantage of LSDV estimates is that by adding the dummy for each country, we estimate the pure effect of each individual explanatory variable, accounting also for unobserved heterogeneity (Greene, 2013).
} 
Blundell and Bond, 1998). Principally we rely on robust two-step "system GMM" estimates which are robust to heteroscedasticity and serial correlation problems (Roodman, 2006). One of the advantages of system GMM is that it utilizes a bigger subset of instruments. ${ }^{10}$ However the drawback of GMM estimation technique is over fitting the endogenous variables, by increasing the number of instruments, thus leading to biased and inconsistent estimates (Roodman, 2008). Following Windmeijer's (2005) proposed correction term which is used in order to deal with the downward bias of standard errors; we apply the xtabond2 Stata command. We consider the lagged dependent variable, bilateral FDI stock and openness as endogenous variables. We exclude distance and other gravity related dummy variables to not allow the overfitting of the endogenous regressors and increasing the number of instruments. Other regressors, like absolute difference in GDP and GDP per capita and absolute differences in labor and capital endowments are treated as strictly exogenous regressors, specified in the instrumental variable (iv) equation. We keep SEE dummy variable in the model to allow for interaction term between SEE-5 dummy variable and our variable of interest, namely inward FDI stock. To deal with the instruments explosion, following Roodman (2008) we consider lag limit of the dependent variable and other endogenous regressors and collapse the instruments.

\section{Data description and empirical analysis}

In our empirical exercise, we use bilateral panel level data for OECD countries ${ }^{11}$, SEE- $5^{12}$ and EU-NMS-10 13 for the period from 1994 to 2010. The dataset contains information on country characteristics based on aggregate level data (Gross Domestic Product, Gross Domestic Product per capita, labor skill endowments, capital endowments and trade costs) and detailed information on the country's exports, imports and foreign direct investments stocks between different countries. Considering the aggregate nature of the data, this research is focused on country level data, using bilateral panel data set between countries.

\footnotetext{
${ }^{10}$ System GMM is more persistent than difference GMM particularly with a higher persistence of the dependent variable and a lower time dimension (Blundell and Bond, 1998), with explanatory variables that are not strictly exogenous (Roodman, 2008).

${ }^{11}$ Austria, Belgium, Denmark, France, Finland, Germany, Greece, Ireland, Italy, the Netherlands, Portugal, Spain, Sweden, the United Kingdom, the United States, Canada, Israel, Norway, Turkey and Switzerland.

${ }^{12}$ Albania, Bosnia and Herzegovina, Croatia, Macedonia and Serbia.

${ }^{13}$ Bulgaria, Romania, Slovenia, the Slovak Republic, the Czech Republic, Hungary, Poland, Latvia, Lithuania and Estonia.
} 
Table 1: FDI and trade in SEE-5 countries, during the period $1994-2010$

- in millions USD

unless otherwise stated

\begin{tabular}{|r|c|c|c|c|c|c|c|c|r|}
\hline Year & Exports & \multicolumn{1}{l|}{ Change } & \multicolumn{1}{l|}{ Imports } & \multicolumn{1}{l|}{ Change } & \multicolumn{2}{l|}{ FDI stock } & \multicolumn{2}{l|}{ Change } \\
\hline 1994 & 0.36 & & & 0.50 & & & 1.33 & & \\
\hline 1995 & 0.31 & -0.05 & -14.38 & 0.59 & 0.09 & 18.14 & 1.10 & -0.23 & -17.04 \\
\hline 1996 & 0.28 & -0.03 & -9.27 & 0.59 & -0.00 & -0.48 & 1.19 & 0.09 & 8.36 \\
\hline 1997 & 0.28 & 0.01 & 1.82 & 0.69 & 0.10 & 16.47 & 1.29 & 0.10 & 8.50 \\
\hline 1998 & 0.29 & 0.00 & 1.44 & 0.64 & -0.05 & -7.21 & 1.59 & 0.30 & 23.00 \\
\hline 1999 & 0.33 & 0.04 & 14.48 & 0.70 & 0.06 & 10.16 & 2.11 & 0.52 & 32.59 \\
\hline 2000 & 0.38 & 0.05 & 16.31 & 0.74 & 0.04 & 5.53 & 2.91 & 0.80 & 37.71 \\
\hline 2001 & 0.34 & -0.04 & -10.51 & 0.75 & 0.00 & 0.61 & 3.01 & 0.10 & 3.54 \\
\hline 2002 & 0.29 & -0.05 & -14.97 & 0.72 & -0.03 & -3.95 & 3.88 & 0.87 & 28.82 \\
\hline 2003 & 0.33 & 0.04 & 14.85 & 0.84 & 0.12 & 17.05 & 4.02 & 0.14 & 3.72 \\
\hline 2004 & 0.43 & 0.09 & 28.15 & 1.09 & 0.25 & 29.69 & 4.18 & 0.16 & 3.91 \\
\hline 2005 & 0.44 & 0.02 & 4.15 & 1.05 & -0.04 & -3.47 & 4.00 & -0.18 & -4.23 \\
\hline 2006 & 0.50 & 0.06 & 13.21 & 1.04 & -0.01 & -1.30 & 5.38 & 1.38 & 34.43 \\
\hline 2007 & 0.48 & -0.02 & -4.46 & 1.13 & 0.09 & 8.88 & 0.85 & -4.53 & -84.18 \\
\hline 2008 & 0.41 & -0.07 & -14.53 & 1.16 & 0.03 & 2.79 & 0.72 & -0.13 & -15.46 \\
\hline 2009 & 0.40 & -0.01 & -3.45 & 0.94 & -0.22 & -19.27 & 0.70 & -0.02 & -2.33 \\
\hline 2010 & 0.43 & 0.04 & 9.02 & 0.94 & 0.00 & 0.46 & 0.88 & 0.17 & 24.57 \\
\hline
\end{tabular}

Notes: FDI stock data in table 1 represent the value of the stock of direct investments held at the end of the reference period; in millions of US dollar. The data on FDI stock represent the outward stock of FDI from source OECD-20 countries into SEE-5 countries as a share of SEE-5 countries GDP. Bilateral exports and imports are converted into millions of US dollar. The data on bilateral exports (imports) represent the export (import) level of SEE-5 countries to OECD-20 countries, as a share of exporting (importing) SEE-5 countries GDP.

Source: Author's calculation

In this section we illustrate the dynamics of outward foreign direct investment flows from OECD-20 countries to SEE-5 and EU-NMS-10 countries as a share of GDP, in relation to the dynamics of bilateral export and import flows as a share of GDP from SEE-5 and EU-NMS-10 to OECD-20 countries, during the period 1994-2010. From 1994, when total stock of outward FDI as a share to GDP to SEE-5 was 1.33 per cent to 2010 it decreased by 0.45 percentage points, to 0.88 per cent, whereas the export flows from SEE-5 to importing countries, during the same period, have increased by 0.07 percentage points, from 0.36 to 0.43 per cent. Also, the data presented in Table 1 outlines a very significant correlation between bilateral outward FDI stock from host to source countries and the increase of import flows from SEE-5 to OECD-20 countries. Focusing on the observed period, from 1994 - 2010, the data confirm that SEE-5 import flows as a share of GDP from OECD-20 have increased at marginal level by 0.49 percentage points, from 0.50 to 0.94 per cent. However, although the bilateral FDI stock as a share of GDP 
Bardhyl Dauti - Trade and foreign direct investment: Evidence from South East...

from source to host countries has decreased enormously, during the last decade, 2000-2010 trade flows (both exports and imports, at bilateral level) from SEE-5 to OECD-20, have increased only at a marginal level. The data presented in Table 2 confirms that, during the observed period from 1994 to 2010, there is some sort of correlation between the increase of outward FDI stock from OECD-20 to EU-NMS-10 countries and the increase of both EU-NMS-10 import flows from OECD-20 countries and EU-NMS-10 export flows to OECD-20 countries.

Table 2: FDI and trade in EU-NMS-10 countries, during the period $1994-2010$

- in millions USD

unless otherwise stated

\begin{tabular}{|r|c|c|c|c|c|c|c|c|r|}
\hline Year & Exports & \multicolumn{1}{l}{ Change } & \multicolumn{1}{l}{ Imports } & \multicolumn{2}{l|}{ Change } & \multicolumn{2}{l|}{ FDI stock } & \multicolumn{2}{l|}{ Change } \\
\hline 1994 & 1.50 & & & 1.67 & & & 0.21 & & \\
\hline 1995 & 1.48 & -0.02 & -1.61 & 1.65 & -0.02 & -1.08 & 0.23 & 0.03 & 12.39 \\
\hline 1996 & 1.60 & 0.12 & 8.37 & 1.87 & 0.22 & 13.60 & 0.42 & 0.19 & 80.86 \\
\hline 1997 & 1.83 & 0.22 & 13.87 & 2.13 & 0.26 & 13.74 & 0.36 & -0.06 & -15.00 \\
\hline 1998 & 1.77 & -0.05 & -3.00 & 2.03 & -0.10 & -4.56 & 0.48 & 0.13 & 35.30 \\
\hline 1999 & 1.88 & 0.11 & 5.97 & 2.06 & 0.03 & 1.41 & 0.69 & 0.20 & 41.82 \\
\hline 2000 & 2.14 & 0.26 & 13.88 & 2.23 & 0.17 & 8.38 & 0.92 & 0.23 & 33.40 \\
\hline 2001 & 2.06 & -0.08 & -3.88 & 2.12 & -0.11 & -5.13 & 1.06 & 0.15 & 15.98 \\
\hline 2002 & 2.01 & -0.05 & -2.20 & 2.02 & -0.10 & -4.90 & 1.18 & 0.11 & 10.74 \\
\hline 2003 & 2.06 & 0.05 & 2.44 & 2.03 & 0.01 & 0.64 & 1.29 & 0.11 & 9.32 \\
\hline 2004 & 2.17 & 0.11 & 5.44 & 2.14 & 0.12 & 5.67 & 1.37 & 0.08 & 6.35 \\
\hline 2005 & 2.14 & -0.03 & -1.33 & 2.08 & -0.07 & -3.05 & 1.27 & -0.10 & -7.27 \\
\hline 2006 & 2.22 & 0.08 & 3.66 & 2.17 & 0.09 & 4.50 & 1.43 & 0.16 & 12.93 \\
\hline 2007 & 2.12 & -0.10 & -4.60 & 2.12 & -0.05 & -2.44 & 1.61 & 0.17 & 12.05 \\
\hline 2008 & 2.11 & -0.01 & -0.52 & 2.11 & -0.01 & -0.60 & 1.40 & -0.20 & -12.61 \\
\hline 2009 & 2.05 & -0.06 & -2.85 & 1.84 & -0.26 & -12.53 & 1.68 & 0.27 & 19.46 \\
\hline 2010 & 2.42 & 0.37 & 18.31 & 2.17 & 0.33 & 17.82 & 1.73 & 0.05 & 2.83 \\
\hline
\end{tabular}

Notes: FDI stock data in table 2 represent the value of the stock of direct investments held at the end of the reference period; in millions of US dollar. The data on FDI stock represent the outward stock of FDI from source OECD-20 countries into EU-NMS-10 countries as a share of EU-NMS-10 countries GDP. Bilateral exports and imports are converted into millions of US dollar. The data on bilateral exports (imports) represent the export (import) level of EU-NMS-10 countries to OECD-20 countries, as a share of exporting (importing) EU-NMS-10 countries GDP.

Source: Author's calculation

During the observed period, FDI outward stock as a share of GDP from OECD-20 to EU-NMS-10 has increased by 1.52 percentage points, from 0.21 per cent to 1.73 per cent, whereas EU-NMS-10 export flows back to OECD-20 and EU-NMS-10 import flows from OECD-20 countries, during the observed period, have increased 0.92 percentage points and 0.5 percentage points respectively. Focusing on the year 
of 2010, the data presented in Tables 1 and 2 confirm that the outward stock of FDI as a share of GDP from OECD-20 to SEE-5 is 1.96 times lower than the outward stock of FDI as a share of GDP from OECD-20 to EU-NMS-10 countries. Also, the export and import flow as a share of GDP from SEE-5 to OECD-20 in comparison to the export and import flow as a share of GDP from EU-NMS-10 to OECD-20 countries are 5.6 and 2.30 times lower, respectively.

Figure 1: Relationship between FDI stock, exports and imports in SEE-5 countries

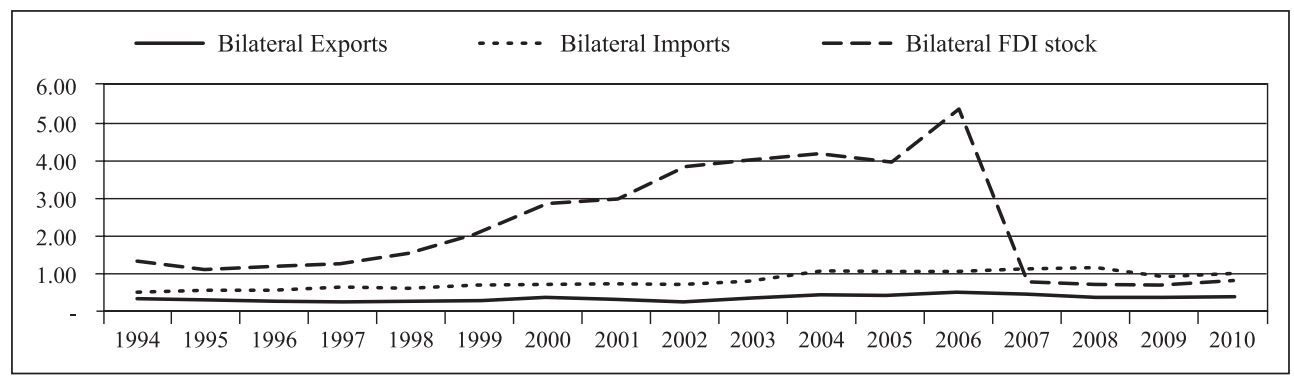

Notes: The data on FDI stock represent the outward stock of FDI from source OECD-20 countries into SEE-5 countries as a share of SEE- 5 countries GDP. The data on bilateral exports (imports) represent the export (import) level of SEE- 5 countries to OECD-20 countries, as a share of exporting (importing) SEE-5 countries GDP.

Source: Author's calculation

In figure 1 and 2, we examine the relationship between bilateral FDI outward stock from OECD-20 to SEE-5 and EU-NMS-10, and trade (exports and imports) at bilateral level from SEE-5 and EU-NMS-10 to OECD-20.

Figure 2: Relationship between FDI stock, exports and imports in EU-NMS-10 countries

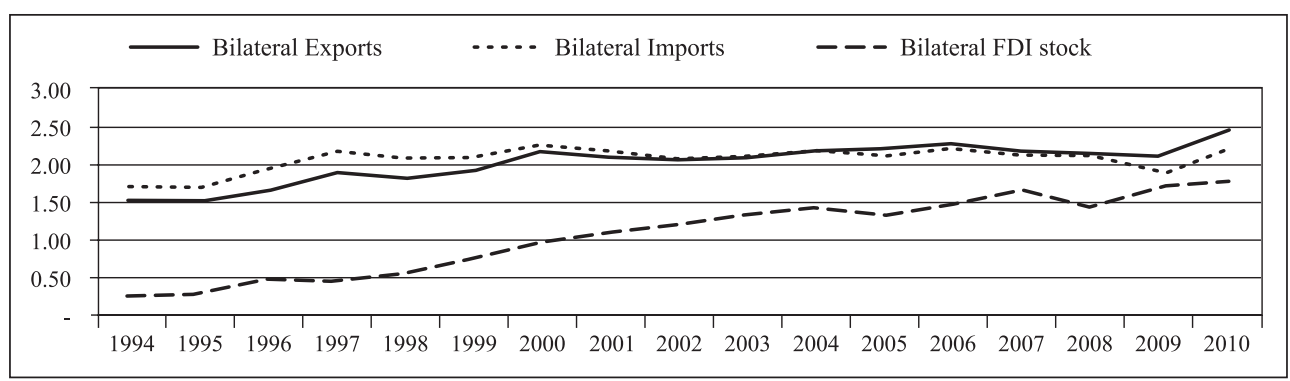

Notes: The data on FDI stock represent the outward stock of FDI from source OECD-20 countries into EU-NMS-10 countries as a share of EU-NMS-10 countries GDP. The data on bilateral exports (imports) represent the export (import) level of EU-NMS-10 countries to OECD-20 countries, as a share of exporting (importing) EU-NMS-10 countries GDP.

Source: Author's calculation 
The highest relative increase of the FDI outward stock from OECD-20 to EU-NMS-10 countries is registered between 2003 and 2004 and from 2006 to 2007, whereas this increase in SEE-5 countries is observed between 2001 and 2006. The increase of FDI outward stock from OECD-20 to SEE-5 countries up to 2006 can be attributed to improvements of country-specific factors of SEE countries, the increased macroeconomic performance of SEE-5 countries and the improvement of SEE-5 country policies toward the attraction of foreign capital, such as subsidies and tax breaks. Moreover, the increased presence of foreign capital in the SEE-5 countries, has led also to the increase of trade performance of SEE countries, at both export and import level, thus enabling the SEE-5 countries to increase their trade flow to OECD-20 countries.

\section{Results and discussion}

In this section we present the empirical results. We discuss the economic interpretation of the models summarized in Tables A7 and A8, in the appendix. All of the above mentioned methodologies are presented for estimating the determinants of bilateral trade at both export and import level between countries.

\subsection{Relationship between bilateral exports and FDI}

In this section we present the empirical results when the dependent variable is the bilateral exports from SEE-5 and EU-NMS-10 to OECD-20 countries. We discuss the economic interpretation of models summarized in table A7 in the appendix, bearing in mind that significant coefficient from robust FE and robust LSDV should be considered for interpretation of the results. To distinguish the effect of FDI stock on exports between SEE-5 and EU-NMS-10 countries, we have included the interaction terms between SEE dummy and FDI stock. By this interaction we test the hypothesis that the effect of the inward stock of FDI on the bilateral exports, in exporting countries, is different between SEE-5 countries and EU-NMS-10 countries. Focusing on the results of FE with year dummy (column 2), the estimated coefficient of bilateral FDI stock for EU-NMS-10 countries, in the equation of bilateral exports is $0.061(0.064-0.137 * 0)$, per cent. For SEE- 5 countries it is -0.073 per cent $(0.064-0.137 * 1)$. The difference of 0.137 percentage point less for SEE-5 countries is statistically significant at 1 per cent level of significance (see Table A7 in the Appendix, column 2 and 7). Thus, we conclude that there is sufficient evidence against the hypothesis that the size of bilateral exports does not vary with respect to the level of FDI stock, between SEE-5 and EU-NMS-10 countries. These results indicate that 10 per cent increase in the bilateral FDI stock from OECD-20 countries to SEE-5 countries, on average, decreases bilateral exports from SEE-5 to OECD-20 countries by 0.7 per cent, ceteris paribus. On the other hand, 10 
per cent increase in bilateral inward FDI stock from OECD-20 to EU-NMS-10 countries, result on increase of bilateral exports from exporting EU-NMS-10 countries to importing OECD-20 countries, by 0.6 per cent, ceteris paribus. This result confirms of the complementarities between stock of FDI and exports in EU-NMS-10 countries, suggesting that FDI in EU-NMS-10 countries are vertically oriented, targeting mainly geographically fragmented production process by stages. In other words the stock of inward of FDI into EU-NMS-10 countries seems to be trade inducing. The estimated negative coefficient FDI stock for SEE-5 countries, indicates that inward FDI stock in SEE-5 countries, are horizontally oriented, which are based on production of homogenous products, thus FDI and exports may be considered as substitutes for each other in the selected SEE- 5 countries.

We find that the coefficient of contingency, in the robust LSDV estimates is positively associated to bilateral FDI stock, as expected. The robust LSDV model (see Table A7 in the Appendix, column 7) predicts that bilateral export flow between two contingent countries is 89.07 per cent higher than bilateral export flow between two non contingent countries ${ }^{14}$. This result means that contingency has strong effect in LSDV estimates (with average enhancement effect of 89.07 per cent). Also, the robust LSDV model accounting for country (exporting and importing) fixed effects and time fixed effects (see Table A7 in the Appendix, column 6), predicts that bilateral export flow between two similar countries in terms of culture and language is 40.91 per cent higher than bilateral export flow between two non similar countries. All the estimated coefficients in LSDV models, have the expected signs, the only exception are the coefficients of openness and same country that seem to have a negative impact if we do not control for country fixed effects and consider only year fixed effects (see Table A7 in the Appendix, columns 3).

The factor endowment coefficients at labor and capital base are both significant and positive at 1 and 5 per cent level of significance in fixed effect estimates with time and country varying exporting and importing dummy. These results confirm the standard trade theory that export increases with differences in relative factor endowments (Helpman and Krugman, 1986). The estimated elasticity of skill endowment difference is very low, 0.141 per cent, meaning that a considerable increase of skill endowment differences between trading partners by 10 per cent increases bilateral exports, on average, by only 1.4 per cent, ceteris paribus. However, again the size of the coefficient of capital endowment differences between countries is very low, meaning that its impact on exports, although positive, is economically very small, confirming that a sizeable increase of the country differences with respect to relative capital endowment by 10 per cent, increases export performance of exporting countries by only 0.8 per cent, ceteris paribus.

\footnotetext{
$\overline{14}$ The formula to compute this effect is $\left(e^{0.637}-1\right) \times 100$ where 0.637 is the estimated coefficient of contingency.
} 
The system GMM estimates confirm that bilateral exports in the estimated coefficient of the lagged dependent variable is positive and significant, suggesting that bilateral export flow is subject to persistence effects. These results indicate that the increase of hysteresis effect of exports by 10 per cent, results in an increase of export flows from exporting countries by 8.4 per cent, ceteris paribus. Considering country characteristics in the system GMM estimates, we find that bilateral exports increase with the differences in GDP and decrease with differences in GDP per capita (The coefficient of difference in GDP is positive and significant and the coefficient of per capita GDP is negative and significant). Interpreting the results from "system GMM" estimates (see Table A7 in the Appendix, column 8), 10 per cent increase in terms of absolute GDP difference between the trading partners, increases the exports flows by 0.4 per cent, ceteris paribus. The same estimates confirm that, 10 per cent increase in terms of absolute GDP per capita difference between countries decreases the exports flows of exporting countries, by 1.8 per cent, ceteris paribus.

\subsection{Relationship between bilateral imports and FDI}

The positive and significant coefficient of bilateral FDI stock for benchmark category of EU-NMS-10 countries indicates that the stock of inward of FDI seems to be trade inducing. However, as in previous case, to distinguish the effect of FDI stock on imports between SEE-5 and EU-NMS-10 countries, we have included an interaction terms between SEE dummy and FDI stock. Referring to robust LSDV estimates, (see Table A8 in the Appendix, column 7), the estimated coefficient of bilateral FDI stock for EU-NMS-10 countries, in the equation of bilateral imports is 0.055 per cent $\left(0.055-0.048^{*} 0\right)$. For SEE- 5 countries it is 0.007 per cent $(0.055$ $\left.0.048^{*} 1\right)$. The difference of 0.048 percentage point less for SEE- 5 countries is economically large and statistically significant at 1 per cent level of significance. Thus, we conclude that there is sufficient evidence against the hypothesis that the size of bilateral imports does not vary with respect to the level of inward FDI. This result indicate that 10 per cent increase of FDI in SEE- 5 countries, originated from OECD-20 countries is associated with an increase of SEE-5 bilateral imports from OECD-20 countries, on average, by 0.07 per cent, ceteris paribus. This result suggests that the impact of inward FDI stock in the host SEE-5 countries from source OECD-20 countries, although positive, is economically very small. The average bilateral imports in the benchmark category of EU-NMS-10 countries are 0.055 per cent, meaning that 10 per cent increase of FDI in EU-NMS-10 countries, originated from OECD-20 countries is associated with an increase of EU-NMS-10 bilateral imports from OECD-20 countries, by 0.5 per cent, ceteris paribus. The positive relationship between inward stock of FDI and imports confirm the complementarities between FDI and imports in SEE-5 and EN-NMS-10 countries. Based on the relationship between bilateral FDI stock and bilateral imports between countries, the equation of imports provide an evidence that FDI in SEE-5 and 
EU-NMS-10 countries are vertically oriented, targeting mainly geographically fragmented production process by stages. In all LSDV estimates (see Table A8 in the Appendix), trade costs substituted by distance variable are negatively related to imports, as expected.

We find that the coefficient of contingency, in the robust LSDV estimates is positively associated to bilateral FDI stock, as expected. The robust LSDV model (see Table A8 in the Appendix, column 6) predicts that bilateral import flow between two contingent countries is 207.40 per cent higher than bilateral export flow between two non contingent countries. This result means that contingency has strong effect in LSDV estimates (with average enhancement effect of 207.40 per cent $)^{15}$. On the other hand, contrary to expectations the coefficient of same country, indicating border, language or cultural similarities is found to have a strong and negative enhancement effect in LSDV estimates with year dummy and LSDV estimates with time invariant and time variant exporting and importing country fixed effects (see Table A8 in the Appendix, columns 3, 4 and 5). Time variant country (exporting and importing) fixed effects provide an evidence that bilateral imports between two countries in terms of culture, language and border similarities is lower, on average by 12.71 per cent than bilateral import flows between two non similar countries. The effect of absolute differences in capital endowments is statistically significant and negative in all relevant estimates (see Table A8 in the Appendix, columns 2, 6 and 7), indicating that 10 per cent increase of the capital endowment differences between trading partners, decreases import flows of SEE-5 and EU-NMS- 10 countries by 0.4 per cent, ceteris paribus. The robust LSDV estimates with year dummy are suggesting that bilateral imports increase with the differences in bilateral GDP and decrease with the differences in GDP per capita, between trading partner countries. Focusing on the results of FE with year dummy, 10 per cent increase in GDP per capita difference between countries leads to, on average, 3.8 per cent decrease of import flows. The system GMM estimates confirm that the estimated coefficient of the lagged dependent variable is positive and significant, suggesting that the increase of hysteresis effect of imports by 1 per cent leads to, on average, to 0.9 per cent increase of import flows, suggesting that import flows are subject to persistence effects. Also, the results confirm negative and statistically significant coefficient of skill endowment variable, indicating that 1 per cent increase in absolute difference in skill endowment between countries, on average, decreases bilateral imports, by 0.01 and 0.005 per cent, respectively, ceteris paribus.

\footnotetext{
$\overline{15}$ The formula to compute this effect is $\left(e^{0.584}-1\right) \times 100$ where 1.123 is the estimated coefficient of contingency.
} 


\section{Conclusions}

The presented results of our analysis proved the hypothesis that FDI have a significant effect on trade for SEE-5 and EU-NMS-10 countries. With regard to the relationship between exports and FDI, the findings of the research showed mixed evidence, supporting vertical FDI for EU-NMS-10 countries and horizontal FDI for SEE-5 countries. On the other hand, the results on the relationship between imports and FDI showed unique evidence, supporting vertical FDI for both group of countries, (SEE-5 and EU-NMS-10). The results also confirm that trade performance between partner countries is maximized when countries are dissimilar in size and similar in economic development, tastes and preferences. This research contributes to the existing body of literature, by examining empirically an Trade-FDI nexus model, to analyze the complementary or substitution relationship between the FDI effect and Trade in SEE-5 and EU-NMS-10 countries. The limitations of this research are pertaining to the data set. Due to the availability of the macro data the empirical analysis has not been carried out on the micro level data, thus neglecting an inter-industry, intraindustry or intra-firm research level analysis, which can provide an alternative option for explaining the complementarities and substitution relationship between trade and FDI. We see a fruitful direction for future research an investigation of the deep forces behind the increase in the complementarities between FDI and trade, found in the estimations. Moreover, a cross-section analysis, using firm and industry level data could shed light on the determinants underlying the differences between SEE-5 and EU-NMS-10 countries trade dynamics. In this regard, explaining the exports to sales ratio in the foreign subsidiaries (in comparison to domestic firms) in the selected countries can provide an alternative option for explaining the horizontal or vertical nature of FDI in the selected countries. The policy implication of the results of this undertaken research are that the internationalization of OECD countries foreign companies, through FDI, does improve the external economic conditions, with respect to trade performance of SEE and new EU member states countries. In the case of exports, vertical FDI associated with high value added activities may have greater impact on exports rather than imports. On the other hand, in the case of imports, vertical FDI associated with low value added activities may serve as an import expansion of intermediate products.

\section{References}

Arrellano, M., Bover, O. (1995) "Another Look at the Instrumental Variable Estimation of Error-Components Models", Journal of Econometrics, Vol. 68, No. 1, pp. 29-51, doi: 10.1016/0304-4076(94)01642-D.

Baldwin, R., Taglioni, D. (2006) "Gravity for Dummies and Dummies for Gravity Equations", National Bureau of Economic Research Working Paper No. 12516, NBER, doi: 10.3386/w12516. 
Bevan, A.A., Estrin, S. (2004) “The Determinants of Foreign Direct Investment into European Transition Economies", Journal of Comparative Economics, Vol. 32, No. 4, pp. 775-787, doi: 10.1016/j.jce.2004.08.006.

Blonigen, B. et al. (2003) "Estimating the Knowledge-Capital Model of the Multinational Enterprise: Comment", American Economic Review, Vol. 93, No. 3, pp. 980-994, doi: 10.1257/000282803322157214.

Blundell, R., Bond, S. (1998) "Initial Conditions and Moment Restrictions in Dynamic Panel Data Models", Journal of Econometrics, Vol. 87, No. 1, pp. 115-143, doi: 10.1016/S0304-4076(98)00009-8.

Bos, J. W. B., Van de Laar, M. (2004) "Explaining foreign direct investment in Central and Eastern Europe: an extended gravity approach", Working Paper No. 008, Netherlands Central Bank, Research Department, Amsterdam, the Netherlands.

Brainard, L. S. (1997) "An Empirical Assessment of the Proximity-Concentration Trade-off Between Multinational Sales and Trade", National Bureau of Economic Research Working paper No. 4580, NBER, pp. 520-544, doi: 10.3386/w4580.

Brainard, L. S., Riker, D. (1997) "Are U.S. Multinationals Exporting U.S. Jobs?" National Bureau of Economic Research Working Paper No. 5958, NBER, doi: 10.3386/w5958.

Carr, D. L., Markusen, J. R., Maskus, K. (2001) "Estimating the Knowledge-Capital Model of the Multinational Enterprise", American Economic Review, Vol. 91, No. 3, pp. 693-708, doi: 10.1257/aer.91.3.693.

Eaton, J. (1985) "Market structure and foreign trade: Increasing returns, imperfect competition and the international economy: Helpman, E., Krugman, P. R.", Journal of International Economics, Vol. 21, No. 1, pp. 183-187, doi: 10.1016/ 0022-1996(86)90014-0.

Ekholm, K., Forslid, R., Markusen, J. R. (2007) "Export-Platform Foreign Direct Investment", Journal of the European Economic Association, Vol. 5, No. 4, pp. 776-795, doi: 10.1162/JEEA.2007.5.4.776.

Feenstra, R. C. (2004) Advanced International Trade: Theory and Evidence, Princeton, NJ: Princeton University Press.

Frankel, J., Stein, E., Wei, Sh. J. (1995) "Trading Blocs and the Americas: The Natural, the Unnatural, and the Super-natural", Journal of Development Economics, Vol. 47, No.1, pp. 61-95, doi: 10.1016/0304-3878(95)00005-4.

Greene, W. H. (2013) Econometric Analysis (5 ${ }^{\text {th }}$ ed.), Upper Saddle River, N.J.: Prentice Hall.

Head, K., Ries, J. (2003) "Heterogeneity and the FDI versus Export Decision of Japanese Manufacturers", Journal of the Japanese and International Economies, Vol. 17, No. 4, pp. 448-467, doi: 10.1016/j.jjie.2003.09.003. 
Helpman, E. (1984) "A simple theory of international trade with multinational corporations", Journal of Political Economy, Vol. 92, No. 3, pp. 451-472, doi: $10.1086 / 261236$.

Helpman, E., Melitz, M. J., Yeaple, S. R. (2004) "Export versus FDI with Heterogeneous Firms", American Economic Review, Vol. 94, No. 1, pp. 300-316, doi: $10.1257 / 000282804322970814$.

Johnson, A. (2006) "FDI inflows to the Transition Economies of Eastern Europe: Magnitude and Determinants", CESIS Electronic Working Paper Series, Paper No 59, The Royal Institute of Technology - Centre for Excellence for Studies in Science and Innovation.

Markusen, J. R. et al. (1996) "A unified treatment of horizontal direct investment, vertical direct investment and the pattern of trade in goods and services", NBER 5696, doi: 10.3386/w5696.

Markusen, J. R. (1998) "Multinational Firms, Location and Trade", The World Economy, Vol. 21, No. 6, pp. 733-756, doi: 10.1111/1467-9701.00161.

Markusen, J. R. (2002) Multinational Firms and the Theory of International Trade, University of Colorado, Boulder: MIT Press.

Martinez, V., Bengoa, M., Robles, B. S. (2012) "Foreign Direct Investment and Trade: Complements or Substitutes? Empirical Evidence for the European Union", Technology and Investment, Vol. 3, No. 2, pp. 105-112, doi: 10.4236/ti.2012.32013.

Resmini, L. (2000) "The Determinants of Foreign Direct Investment in the CEECs: New evidence from sectoral patterns", The Economics of Transition, Vol. 8, No. 3, pp. 665-689, doi: 10.1111/1468-0351.00060.

Riker, D., Brainard, L. S. (1997) "U.S. Multinationals and Competition from Low Wage Countries", National Bureau of Economic Research Working Paper No. 5959, NBER, doi: 10.3386/w5959.

Roodman, D. (2009) "How to Do Xtabond2: An Introduction to Difference and System GMM in Stata", Working paper, No. 103, Center for global development, doi: $10.2139 /$ ssrn. 982943 .

Roodman, D. (2009) "A Note on the Theme of Too Many Instruments", Oxford Bulletin of Economics and Statistics, Vol. 71, No. 1, pp. 135-158, doi: 10.1111/j.1468-0084.2008.00542.x.

Rose, A. K, Wincoop, V. E. (2001) "National Money as a Barrier to International Trade: The Real Case for Currency Union", American Economic Review, Vol. 91, No. 2, pp. 386-390, doi: 10.1257/aer.91.2.386.

Shatz, H. J., Venables, A. J. (2000) "The geography of International Investment", World Bank Policy Research Working Paper, No. 2338.

Windmeijer, F. (2005) "A finite sample correction for the variance of linear efficient two-step GMM estimators", Journal of Econometrics, Vol. 126, No. 1, pp. 25-51, doi: 10.1016/j.jeconom.2004.02.005. 


\title{
Trgovina i izravne strane investicije na primjeru zemalja Jugoistočne Europe i novih članica Europske unije ${ }^{1}$
}

\author{
Bardhyl Dauti ${ }^{2}$
}

\begin{abstract}
Sažetak
Cilj ovog istraživanja je utvrditi postojanje komplementarne odnosno supstitucijske veze između međunarodne trgovine i izravnih stranih investicija (ISI) uzevši u obzir obilježja gospodarstva. Istraživanje se temelji na podacima o ISI i trgovini u razdoblju 1994. - 2010. U istraživanju je korišten prošireni gravitacijski model kako bi se testirala veza između međunarodnih trgovinskih tijekova (izvoz i uvoz), razine FDI i nacionalnih karakteristika OECD 20 zemalja, 5 zemalja Jugoistočne Europe (5-JIE) i 10 novih članica EU (10-NCEU). Empirijski model analizira na koji način veza između ISI i međunarodne trgovine određuje horizontalnu odnosno vertikalnu prirodu ISI iz OECD-20 zemalja prema 5-JIE i 10-NCEU zemljama. Rezultati veze između izvoza i ISI ukazuju na postojanje vertikalnog ISI u 10-NCEU zemljama $i$ horizontalnog ISI u 5-JIE zemljama. S druge strane, temeljem veze između uvoza i ISI, rezultati upućuju na vertikalnu prirodu ISI u obje prethodno spomenute skupine zemalja. Osnovni zaključak istraživanja je da dokazi upućuju na miješanu prirodu ISI u 5-JIE i 10-NCEU zemljama te na postojanje i komplementarne i supstitucijske veze između trgovine i ISI u ovim zemljama.
\end{abstract}

Ključne riječi: izravna strana ulaganja, trgovina, dopune, supstituti, gravitacijski model

JEL klasifikacija: F12, F14, F21, F23

1 Za konstruktivnu raspravu i korisne komentare prilikom izlaganja ovoga rada na doktorskoj konferenciji organiziranoj od strane Ekonomskog fakulteta Sveučilišta u Ljubljani (FEUL), 11. lipnja 2014. godine, autor Bardhyl Dauti želi izraziti svoju zahvalnost profesorima Joži P. Damijanu, Črt Kostevcu, Matiji Rojcu i Anži Burgeru, kao i dvojici anonimnih recenzenata časopisa Zbornik radova Ekonomskog fakulteta u Rijeci: časopis za ekonomsku teoriju i praksu/ Proceedings of Rijeka Faculty of Economics: Journal of Economics and Business.

${ }^{2}$ Docent, Fakultet ekonomije, Sveučilište u Tetovu, Ilindenska ulica, 1200 Tetovo, Makedonija. Znanstveni interes: makroekonomija, međunarodna razmjena, suvremeni ekonomski sustavi. E-mail: bardhyl.dauti@unite.edu.mk. 
Bardhyl Dauti $\bullet$ Trade and foreign direct investment: Evidence from South East...

Zb. rad. Ekon. fak. Rij. • $2016 \cdot$ vol. $34 \cdot$ no. $1 \cdot 63-89$

\section{Appendices}



Bardhyl Dauti - Trade and foreign direct investment: Evidence from South East...

Table A1: Descriptive statistics

\begin{tabular}{|l|c|c|c|c|c|}
\hline \multicolumn{1}{|c|}{ Variable } & Obs & Mean & Std.Dev & Min & Max \\
\hline Log of bilateral exports & 4,414 & 4.53 & 2.31 & 0.00 & 12.26 \\
\hline Log of bilateral imports & 4,488 & 4.99 & 1.98 & 0.00 & 12.26 \\
\hline Log of bilateral FDI stock & 5,099 & 2.37 & 3.04 & 0.00 & 11.57 \\
\hline Log of absolute difference in GDP & 5,099 & 12.91 & 1.39 & 3.04 & 16.53 \\
\hline Log of absolute difference in GDP per capita & 5,099 & 9.91 & 0.78 & 3.23 & 11.42 \\
\hline Log of distance & 5,100 & 7.34 & 0.74 & 4.09 & 8.96 \\
\hline Contingency, dummy variable & 5,100 & 0.04 & 0.19 & 0.00 & 1.00 \\
\hline Same country, dummy variable & 5,100 & 0.02 & 0.14 & 0.00 & 1.00 \\
\hline Log of openness & 4,899 & 4.57 & 0.34 & 3.40 & 5.16 \\
\hline Log of absolute difference of labour endowment & 5,098 & 2.71 & 0.76 & -2.30 & 4.01 \\
\hline Log of absolute difference of capital endowment & 5,099 & 9.96 & 1.82 & 1.84 & 14.19 \\
\hline Log of bilateral FDI stock $\times$ SEE dummy & 5,100 & 0.35 & 1.34 & 0.00 & 11.57 \\
\hline SEE-5 dummy & 5,100 & 0.33 & 0.47 & 0 & 1 \\
\hline
\end{tabular}

Source: Author's calculation

Table A2: Correlation matrix between bilateral exports and explanatory variables

\begin{tabular}{|l|r|r|r|r|r|r|r|r|r|r|r|r|}
\hline \multicolumn{1}{|c|}{ Model of exports } & lbex & lfdis & ldgdp & ldgdpc & ldist & cont & smctr & lop & ldem & ldcap & lfdsd & sd \\
\hline Lbex & 1.0 & & & & & & & & & & & \\
\hline Lfdis & 0.7 & 1.0 & & & & & & & & & & \\
\hline Ldgdp & 0.2 & 0.2 & 1.0 & & & & & & & & & \\
\hline ldgdp & 0.0 & 0.3 & 0.1 & 1.0 & & & & & & & & \\
\hline ldist & -0.3 & -0.3 & 0.4 & 0.0 & 1.0 & & & & & & & \\
\hline cont & 0.3 & 0.2 & 0.0 & -0.1 & -0.5 & 1.0 & & & & & & \\
\hline smcty & 0.1 & 0.2 & -0.1 & 0.0 & -0.5 & 0.6 & 1.0 & & & & & \\
\hline lop & 0.1 & 0.0 & 0.1 & 0.0 & -0.1 & 0.1 & 0.1 & 1.0 & & & & \\
\hline ldems & -0.1 & 0.1 & 0.1 & 0.4 & 0.2 & -0.1 & -0.1 & -0.4 & 1.0 & & & \\
\hline ldcap & 0.0 & 0.1 & -0.1 & 0.2 & 0.0 & 0.0 & 0.0 & 0.3 & -0.1 & 1.0 & & \\
\hline lfdis & -0.2 & 0.0 & 0.1 & 0.1 & -0.2 & 0.0 & 0.1 & -0.2 & 0.1 & 0.1 & 1.0 & \\
\hline see-d & -0.4 & -0.2 & 0.1 & 0.1 & -0.1 & 0.0 & 0.1 & -0.3 & 0.2 & 0.1 & 0.9 & 1.0 \\
\hline
\end{tabular}

Source: Author's calculation 
Table A3: Correlation matrix between bilateral imports and explanatory variables

\begin{tabular}{|l|r|r|r|r|r|r|r|r|r|r|l|l|}
\hline Model of imports & lbim & lfdis & ldgdp & ldgdpc & ldist & cont & smctry & lop & ldems & ldcap & lfdsd & sd \\
\hline lbim & 1.0 & & & & & & & & & & & \\
\hline lfdis & 0.8 & 1.0 & & & & & & & & & & \\
\hline ldgdp & 0.3 & 0.1 & 1.0 & & & & & & & & & \\
\hline ldgdpc & 0.1 & 0.3 & 0.1 & 1.0 & & & & & & & & \\
\hline ldist & -0.3 & -0.3 & 0.4 & 0.0 & 1.0 & & & & & & & \\
\hline cont & 0.3 & 0.2 & 0.0 & -0.1 & -0.5 & 1.0 & & & & & & \\
\hline smctr & 0.1 & 0.2 & -0.1 & 0.0 & -0.5 & 0.6 & 1.0 & & & & & \\
\hline lop & 0.0 & 0.0 & 0.1 & 0.0 & -0.1 & 0.1 & 0.1 & 1.0 & & & & \\
\hline ldems & 0.0 & 0.1 & 0.1 & 0.4 & 0.2 & -0.1 & -0.1 & -0.4 & 1.0 & & & \\
\hline ldcap & 0.0 & 0.1 & -0.1 & 0.2 & 0.0 & 0.0 & 0.0 & 0.3 & -0.1 & 1.0 & & \\
\hline lfdis & 0.0 & 0.0 & 0.1 & 0.1 & -0.2 & 0.0 & 0.1 & -0.2 & 0.1 & 0.1 & 1.0 & \\
\hline see-d & -0.2 & -0.2 & 0.1 & 0.1 & -0.1 & 0.0 & 0.1 & -0.3 & 0.2 & 0.1 & 0.9 & 1.0 \\
\hline
\end{tabular}

Source: Author's calculation

Table A4: Description of variables and measurement units

\begin{tabular}{|c|c|c|}
\hline Variable label & Measurement unit & Source \\
\hline $\mathrm{X}_{\mathrm{jit}}$ & $\begin{array}{l}\text { Bilateral trade (exports and imports) in goods from SEE- } 5 \text { and } \\
\text { EU-NMS-10 to OECD- } 20 \text { countries. In millions of US dollar. In } \\
\text { logarithm }\end{array}$ & OECD \\
\hline $\operatorname{lnFDI}_{\mathrm{ijt}-1}$ & $\begin{array}{l}\text { FDI outward stock of Source OECD-20 Countries: FDI stock } \\
\text { from source OECD- } 20 \text { countries to host SEE-5 and EU-NMS-10 } \\
\text { countries. In millions of US dollar. In logarithm }\end{array}$ & OECD \\
\hline $\ln \left|\mathrm{GDP}_{\mathrm{it}-1}-\mathrm{GDP}_{\mathrm{jt}-1}\right|$ & $\begin{array}{l}\text { Absolute difference in GDP between OECD-20 countries and } \\
\text { SEE-5 and EU-NMS-10 countries. Gross Domestic Product (GDP) } \\
\text { measured in millions of US dollar. At current prices. In logarithm }\end{array}$ & UNCTAD \\
\hline $\ln \left|\mathrm{GDPc}_{\mathrm{it}-1}-\mathrm{GDPc}_{\mathrm{jt}-1}\right|$ & $\begin{array}{l}\text { Absolute difference in GDP per capita between OECD-20 countries } \\
\text { and SEE- } 5 \text { and EU-NMS- } 10 \text { countries. GDP per capita, is measured } \\
\text { as the ratio of GDP to Population }\end{array}$ & UNCTAD \\
\hline $\operatorname{lnOP} \mathrm{P}_{\mathrm{j}, \mathrm{t}-1}$ & $\begin{array}{l}\text { Openness: (Export of goods and services + Imports of goods and } \\
\text { services)/GDP. in logarithm }\end{array}$ & UNCTAD \\
\hline $\operatorname{LnD}_{\mathrm{ij}, \mathrm{t}}$ & $\begin{array}{l}\text { Distance in kilometers between capital cities of host and source } \\
\text { countries, in logarithm }\end{array}$ & CEPII \\
\hline SMCTRY & $\begin{array}{l}\text { Dummy variables that take value one when two countries share } \\
\text { a border, a language or were the same country in the past, } \\
\text { correspondingly and zero, otherwise }\end{array}$ & CEPII \\
\hline CONTIG & $\begin{array}{l}\text { Dummy variable that take value one when two countries are } \\
\text { contiguous, } 0 \text { otherwise }\end{array}$ & CEPII \\
\hline $\ln \left|\mathrm{SKILL}_{\mathrm{it}-1}-\mathrm{SKILL}_{\mathrm{jt}-1}\right|$ & $\begin{array}{l}\text { Difference in employment in service sector (as a per centage of total } \\
\text { employment), between source OECD-20 and host SEE-5 and } \\
\text { EU-NMS-10 countries. }\end{array}$ & World Bank \\
\hline $\ln \left|\mathrm{CAP}_{\mathrm{it}-1}-\mathrm{CAP}_{\mathrm{jt}-1}\right|$ & $\begin{array}{l}\text { Gross fixed capital formation in relative to total employment. The } \\
\text { absolute difference of the country } \mathrm{i}(\mathrm{OECD}-20) \text { ratio less the ratio } \\
\text { for country } \mathrm{j} \text { (SEE-5 and EU-NMS-10), was taken }\end{array}$ & World Bank \\
\hline $\operatorname{lnFDI}{ }_{i, t, t-1} \times \mathrm{SEE}$ & Interaction terms between bilateral FDI stock and SEE dummy & Own knowledge \\
\hline SEE & $\begin{array}{l}\text { SEE-5 equal } 1 \text { for SEE-5 countries; } 0 \text { - otherwise, capturing the } \\
\text { benchmark category of EU-NMS-10 countries }\end{array}$ & Own knowledge \\
\hline
\end{tabular}

Source: Author's calculation 
Bardhyl Dauti - Trade and foreign direct investment: Evidence from South East...

Table A5: Performed tests of the static panel model of bilateral exports

\begin{tabular}{|l|l|c|}
\hline Hausman Test & $\chi^{2}(7)\left[\mathrm{p}>\chi^{2}\right]$ & $203.81[0.00]^{* * *}$ \\
\hline Breuch - Pagan LM test & $\chi^{2}(1)\left[\mathrm{p}>\chi^{2}\right]$ & $3184.11[0.00]^{* * *}$ \\
\hline Parameter test & $\mathrm{F}(16,1695)[\mathrm{p}>\mathrm{F}]$ & $100.81[0.00]^{* * *}$ \\
\hline Robust FE vs Robust RE: Sargan-Hansen statistic & SH statistics, $\chi^{2}(7)\left[\mathrm{p}>\chi^{2}\right]$ & $68.405[0.00]^{* * *}$ \\
\hline Wald Test for heteroscedasticity & $\chi^{2}(213)\left[\mathrm{p}>\chi^{2}\right]$ & $9.4 \mathrm{e}+29[0.00]^{* * *}$ \\
\hline Wooldridge test for serial correlation & $\mathrm{F}(1,179)[\mathrm{p}>\mathrm{F}]$ & $96.611[0.00]^{* * *}$ \\
\hline
\end{tabular}

Notes: Dependent variable is $\log$ bilateral export flow. t-statistics in brackets, ${ }^{* * *}$, indicate significance of coefficients at 1 per cent level.

Source: Author's calculation

Table A6: Performed tests of the static panel model of bilateral imports

\begin{tabular}{|l|l|c|}
\hline Hausman Test & $\chi^{2}(7)\left[\mathrm{p}>\chi^{2}\right]$ & $321.45[0.00]^{* * *}$ \\
\hline Breuch - Pagan LM test & $\chi^{2}(1)\left[\mathrm{p}>\chi^{2}\right]$ & $5366.41[0.00]^{* * *}$ \\
\hline Parameter test & $\mathrm{F}(16,1702)[\mathrm{p}>\mathrm{F}]$ & $150.76[0.00]^{* * *}$ \\
\hline Robust FEvs Robust RE: Sargan-Hansen statistic & SH statistics, $\chi^{2}(7)\left[\mathrm{p}>\chi^{2}\right]$ & $153.039[0.00]^{* * *}$ \\
\hline Wald Test for heteroscedasticity & $\chi^{2}(213)\left[\mathrm{p}>\chi^{2}\right]$ & $32906.83[0.00]^{* * *}$ \\
\hline Woldridge test for serial correlation & $\mathrm{F}(1,180)[\mathrm{p}>\mathrm{F}]$ & $103.147[0.00]^{* * *}$ \\
\hline
\end{tabular}

Notes: Dependent variable is $\log$ bilateral import flow. t-statistics in brackets, ${ }^{* * *}$, indicate significance of coefficients at 1 per cent level.

Source: Author's calculation

In both tables (A5 and A6), the performed tests confirm the presence of panel effect in the data (referring to Breuch - Pagan LM test) and the existence of individual fixed effects (referring to Hausman test). The Wald test and Wooldridge test showed that the disturbances are heteroscedastic and serially correlated, in both models, enabling us to estimate the robust version of the FE and RE models which are robust to heteroscedasticity and serial correlation, at the same time. A Sargan Hansen statistic is performed in order to choose among robust $\mathrm{RE}$ and robust FE estimates for interpreting the results, which suggest the selection of robust FE estimates in both models. The parameter test indicate the significance of year dummies in the model of exports and imports, therefore, year dummies are included in the selected robust FE model. 
Bardhyl Dauti $\bullet$ Trade and foreign direct investment: Evidence from South East...

Table A7: Results from the relationship between exports and FDI

\begin{tabular}{|c|c|c|c|c|c|c|c|c|}
\hline Model of exports & (1) & (2) & (3) & (4) & $(5)$ & (6) & (7) & $(8)$ \\
\hline Variables & Robust FE & Robust FE & $\begin{array}{l}\text { Robust } \\
\text { LSDV }\end{array}$ & $\begin{array}{l}\text { Robust } \\
\text { LSDV }\end{array}$ & $\begin{array}{l}\text { Robust } \\
\text { LSDV }\end{array}$ & $\begin{array}{l}\text { Robust } \\
\text { LSDV }\end{array}$ & $\begin{array}{l}\text { Robust } \\
\text { LSDV }\end{array}$ & $\begin{array}{l}\text { System } \\
\text { GMM }\end{array}$ \\
\hline \multirow[t]{2}{*}{$\ln X_{\mathrm{jit}-1}$} & & & & & & & & $0.843^{* * *}$ \\
\hline & & & & & & & & {$[12.74]$} \\
\hline \multirow[t]{2}{*}{$\operatorname{lnFDI} I_{\mathrm{ijt}-1}$} & $0.261^{* * * *}$ & $0.064^{* * *}$ & $0.438^{* * * *}$ & $0.197^{* * *}$ & $0.119^{* * *}$ & $0.064^{* * *}$ & $0.064^{* * *}$ & $0.085^{* *}$ \\
\hline & {$[11.62]$} & {$[2.64]$} & {$[26.87]$} & {$[11.81]$} & {$[6.62]$} & {$[3.58]$} & {$[3.58]$} & [2.04] \\
\hline \multirow[t]{2}{*}{$\ln \left|\mathrm{GDP}_{\mathrm{it}-1}-\mathrm{GDP}_{\mathrm{jt}-1}\right|$} & $0.137^{* *}$ & 0.005 & $0.326^{* * *}$ & $0.106^{* *}$ & -0.003 & 0.005 & 0.005 & $0.042^{*}$ \\
\hline & {$[2.01]$} & {$[0.18]$} & {$[11.71]$} & {$[2.21]$} & {$[-0.10]$} & {$[0.20]$} & {$[0.20]$} & {$[1.67]$} \\
\hline \multirow[t]{2}{*}{$\ln \left|\mathrm{GDPc}_{\mathrm{it}-1}-\mathrm{GDP}_{\mathrm{jt}-1}\right|$} & $0.501^{* * *}$ & 0.080 & $-0.602^{* * *}$ & $0.272^{* * *}$ & -0.033 & 0.080 & 0.080 & $-0.099^{*}$ \\
\hline & [4.33] & {$[0.92]$} & {$[-5.98]$} & {$[2.82]$} & {$[-0.26]$} & {$[0.84]$} & {$[0.84]$} & {$[-1.82]$} \\
\hline \multirow[t]{2}{*}{$\operatorname{lnD_{i,j,t}}$} & & & $-0.523^{* * *}$ & $-0.955^{* * *}$ & $-1.180^{* * *}$ & $-1.024^{* * *}$ & $-0.747^{* * *}$ & \\
\hline & & & {$[-10.10]$} & {$[-15.76]$} & {$[-19.66]$} & {$[-22.77]$} & {$[-4.05]$} & \\
\hline \multirow[t]{2}{*}{ CONTIG } & & & $0.291^{* * *}$ & 0.062 & $0.111^{*}$ & $3.834^{* * *}$ & $0.637^{* * *}$ & \\
\hline & & & {$[2.78]$} & {$[0.86]$} & {$[1.67]$} & {$[26.98]$} & {$[3.52]$} & \\
\hline \multirow[t]{2}{*}{ SMCTRY } & & & $-0.352^{* * *}$ & $0.391^{* * *}$ & $0.343^{* * *}$ & $3.307^{* * *}$ & 0.459 & \\
\hline & & & {$[-3.19]$} & {$[3.21]$} & {$[3.00]$} & {$[6.61]$} & {$[0.43]$} & \\
\hline \multirow[t]{2}{*}{$\operatorname{lnOP}_{\mathrm{jt}-1}$} & $0.820^{* * *}$ & $0.312^{* *}$ & $-0.562^{* * *}$ & $1.306^{* * *}$ & $0.572^{* * *}$ & $0.312^{* * *}$ & $0.312^{* * *}$ & $-0.499^{* *}$ \\
\hline & {$[4.98]$} & {$[2.26]$} & {$[-4.39]$} & {$[7.68]$} & {$[2.98]$} & {$[2.75]$} & {$[2.75]$} & {$[-2.02]$} \\
\hline \multirow[t]{2}{*}{$\ln \left|\mathrm{SKIL}_{\mathrm{it}-1}-\mathrm{SKIL}_{\mathrm{jt}-1}\right|$} & 0.025 & 0.030 & -0.005 & 0.108 & $0.141^{* *}$ & 0.030 & 0.030 & -0.075 \\
\hline & {$[0.39]$} & {$[0.55]$} & {$[-0.08]$} & {$[1.56]$} & {$[2.43]$} & {$[0.57]$} & {$[0.57]$} & {$[-1.46]$} \\
\hline \multirow[t]{2}{*}{$\ln \left|\mathrm{CAP}_{\mathrm{it}-1-1}-\mathrm{CAP}_{\mathrm{jt}-1}\right|$} & $0.097^{* *}$ & 0.039 & $0.024^{*}$ & $0.105^{* * *}$ & $0.085^{* * *}$ & $0.039^{* * *}$ & $0.039^{* * *}$ & 0.017 \\
\hline & {$[2.51]$} & {$[1.63]$} & {$[1.77]$} & [4.99] & [5.33] & {$[2.71]$} & {$[2.71]$} & [1.25] \\
\hline \multirow[t]{2}{*}{$\operatorname{lnFDI}{ }_{\mathrm{ijt}-1}^{*} \mathrm{SEE}$} & $-0.153^{* * *}$ & $-0.137^{* * *}$ & 0.039 & $0.090^{* * *}$ & $0.109^{* * *}$ & $-0.137^{* * *}$ & $-0.137^{* * *}$ & 0.012 \\
\hline & {$[-4.92]$} & {$[-3.22]$} & {$[0.92]$} & {$[3.28]$} & [3.99] & {$[-4.60]$} & {$[-4.60]$} & {$[0.29]$} \\
\hline \multirow[t]{2}{*}{ SEE } & & & $-1.822^{* * * *}$ & & & $-1.952^{* * *}$ & -0.429 & -0.378 \\
\hline & & & {$[-8.06]$} & & & {$[-10.16]$} & {$[-0.49]$} & {$[-1.23]$} \\
\hline \multirow[t]{2}{*}{ Constant } & $-6.986^{* * *}$ & $1.900^{*}$ & $11.567^{* * *}$ & -0.011 & $9.507^{* * *}$ & $10.191^{* * *}$ & $6.684^{* * *}$ & $3.377^{* * *}$ \\
\hline & {$[-5.01]$} & {$[1.82]$} & [9.73] & {$[-0.01]$} & {$[7.01]$} & {$[7.57]$} & {$[3.66]$} & [3.54] \\
\hline Arellano-Bond, AR(1) & N/A & N/A & N/A & N/A & N/A & N/A & N/A & 0.000 \\
\hline Arellano-Bond, AR(2) & N/A & N/A & $\mathrm{N} / \mathrm{A}$ & N/A & $\mathrm{N} / \mathrm{A}$ & N/A & N/A & 0.923 \\
\hline Number of instruments & N/A & N/A & $\mathrm{N} / \mathrm{A}$ & N/A & $\mathrm{N} / \mathrm{A}$ & N/A & N/A & 31 \\
\hline Wald statistics, p-value & N/A & N/A & N/A & N/A & N/A & N/A & N/A & 0.000 \\
\hline Sargan test, p-value & N/A & N/A & N/A & N/A & N/A & N/A & N/A & 0.316 \\
\hline Hansen test, p-value & N/A & N/A & N/A & N/A & N/A & N/A & N/A & 0.953 \\
\hline Time FE & No & Yes & Yes & No & Yes & Yes & Yes & Yes \\
\hline Exporter FE & No & No & No & Yes & Yes & No & Yes & No \\
\hline Importer FE & No & No & No & Yes & Yes & No & Yes & No \\
\hline Country-pair FE & No & No & No & No & No & Yes & Yes & No \\
\hline Observations & 1,931 & 1,931 & 1,931 & 1,931 & 1,931 & 1,931 & 1,931 & 2,101 \\
\hline R-squared & 0.518 & 0.753 & 0.692 & 0.829 & 0.863 & 0.968 & 0.968 & \\
\hline Number of groups & 213 & 213 & 213 & 213 & 213 & 213 & 213 & \\
\hline
\end{tabular}

Notes: Dependent variable is log bilateral export flow from SEE-5 and EU-NMS-10 countries to OECD-20. z-statistics in brackets, ${ }^{* * *},{ }^{* *}$ and ${ }^{*}$ indicate significance of coefficients at 1,5 and 10 per cent, respectively. Column (8): Internal instruments are used for endogenous variables (lagged dependent variable, bilateral FDI stock, and openness). Lag limits are $1 / 2$ for the lagged dependent variable and 4/7 for endogenous regressors. The collapse option is always used. N/A denotes not applicable result.

Source: Author's calculation 
Bardhyl Dauti • Trade and foreign direct investment: Evidence from South East...

Zb. rad. Ekon. fak. Rij. • $2016 \cdot$ vol. $34 \cdot$ no. $1 \cdot 63-89$

Table A8: Results from the relationship between imports and FDI

\begin{tabular}{|c|c|c|c|c|c|c|c|c|}
\hline Model of imports & (1) & (2) & (3) & (4) & (5) & (6) & (7) & (8) \\
\hline Variables & Robust FE & Robust FE & $\begin{array}{l}\text { Robust } \\
\text { LSDV }\end{array}$ & $\begin{array}{l}\text { Robust } \\
\text { LSDV }\end{array}$ & $\begin{array}{l}\text { Robust } \\
\text { LSDV }\end{array}$ & $\begin{array}{l}\text { Robust } \\
\text { LSDV }\end{array}$ & $\begin{array}{l}\text { Robust } \\
\text { LSDV }\end{array}$ & $\begin{array}{l}\text { System } \\
\text { GMM }\end{array}$ \\
\hline \multirow[t]{2}{*}{$\ln X_{\mathrm{jit}-1}$} & & & & & & & & $0.903^{* * *}$ \\
\hline & & & & & & & & {$[15.44]$} \\
\hline \multirow[t]{2}{*}{$\operatorname{lnFDI}{ }_{\mathrm{ijt}-1}$} & $0.208^{* * *}$ & $0.055^{* * *}$ & $0.428^{* * *}$ & $0.216^{* * *}$ & $0.168^{* * *}$ & $0.055^{* * *}$ & $0.055^{* * *}$ & $0.064^{*}$ \\
\hline & {$[10.45]$} & [3.12] & [32.25] & [18.46] & {$[14.36]$} & [4.83] & [4.83] & [1.69] \\
\hline \multirow[t]{2}{*}{$\ln \left|\mathrm{GDP}_{\mathrm{it}-1}-\mathrm{GDP}_{\mathrm{jt}-1}\right|$} & $0.130^{* * *}$ & 0.012 & $0.359^{* * *}$ & 0.050 & -0.038 & 0.012 & 0.012 & 0.014 \\
\hline & [2.78] & {$[0.63]$} & {$[13.70]$} & [1.34] & {$[-1.41]$} & {$[0.79]$} & {$[0.79]$} & {$[0.83]$} \\
\hline \multirow[t]{2}{*}{$\ln \left|G \mathrm{Cc}_{\mathrm{it}-1}-\mathrm{GDPc}_{\mathrm{jt}-1}\right|$} & $0.390^{* * *}$ & -0.025 & $-0.388^{* * *}$ & $0.216^{* * *}$ & -0.060 & -0.025 & -0.025 & $-0.072^{* *}$ \\
\hline & {$[3.80]$} & {$[-0.43]$} & {$[-8.23]$} & [3.45] & {$[-1.00]$} & {$[-0.54]$} & {$[-0.54]$} & {$[-2.21]$} \\
\hline \multirow[t]{2}{*}{$\ln D_{\mathrm{ij}, \mathrm{t}}$} & & & $-0.527^{* * *}$ & $-0.683^{* * *}$ & $-0.830^{* * *}$ & $-0.792^{* * *}$ & $-0.530^{* * *}$ & \\
\hline & & & {$[-11.83]$} & {$[-15.04]$} & {$[-18.70]$} & {$[-23.25]$} & {$[-7.01]$} & \\
\hline \multirow[t]{2}{*}{ CONTIG } & & & $0.260^{* * * *}$ & $0.400^{* * *}$ & $0.444^{* * *}$ & $1.458^{* * *}$ & $1.123^{* * *}$ & \\
\hline & & & {$[3.62]$} & {$[5.77]$} & {$[6.86]$} & {$[21.15]$} & {$[12.49]$} & \\
\hline \multirow[t]{2}{*}{ SMCTRY } & & & $-0.588^{* * *}$ & $-0.280^{* * *}$ & $-0.316^{* * *}$ & -0.025 & 0.498 & \\
\hline & & & {$[-6.95]$} & {$[-2.82]$} & {$[-3.49]$} & {$[-0.15]$} & {$[1.27]$} & \\
\hline \multirow[t]{2}{*}{$\operatorname{lnOP}_{\mathrm{jt}-1}$} & $0.675^{* * *}$ & 0.083 & $-0.902^{* * *}$ & $0.797^{* * *}$ & 0.211 & 0.083 & 0.083 & -0.010 \\
\hline & [5.51] & [1.02] & {$[-9.82]$} & [4.64] & [1.14] & {$[1.08]$} & [1.08] & {$[-0.06]$} \\
\hline \multirow[t]{2}{*}{$\ln \left|\mathrm{SKIL}_{\mathrm{it}-1}-\mathrm{SKIL}_{\mathrm{jt}-1}\right|$} & 0.041 & 0.004 & $-0.155^{* * *}$ & -0.029 & -0.027 & 0.004 & 0.004 & -0.015 \\
\hline & {$[0.68]$} & {$[0.11]$} & {$[-4.28]$} & {$[-0.72]$} & {$[-0.83]$} & {$[0.14]$} & {$[0.14]$} & {$[-0.55]$} \\
\hline \multirow[t]{2}{*}{$\ln \left|\mathrm{CAP}_{\mathrm{it}-1}-\mathrm{CAP}_{\mathrm{jt-1}-1}\right|$} & 0.001 & $-0.043^{* *}$ & -0.006 & 0.022 & 0.006 & $-0.043^{* * *}$ & $-0.043^{* * *}$ & -0.013 \\
\hline & {$[0.05]$} & {$[-2.15]$} & {$[-0.49]$} & {$[1.27]$} & {$[0.44]$} & {$[-3.48]$} & {$[-3.48]$} & {$[-1.35]$} \\
\hline \multirow[t]{2}{*}{$\operatorname{lnFDI}{ }_{\mathrm{ijt}-1}{ }^{*} \mathrm{SEE}$} & $-0.058^{* *}$ & $-0.048^{* *}$ & -0.048 & $0.035^{*}$ & $0.044^{* *}$ & $-0.048^{* * *}$ & $-0.048^{* * *}$ & -0.026 \\
\hline & {$[-2.12]$} & {$[-2.06]$} & {$[-1.45]$} & [1.71] & {$[2.22]$} & {$[-2.94]$} & {$[-2.94]$} & {$[-1.06]$} \\
\hline \multirow[t]{2}{*}{ SEE } & & & $-0.457^{* * *}$ & $-0.817^{* * *}$ & $-1.526^{* * *}$ & $1.087^{* * *}$ & $-1.441^{* * *}$ & 0.100 \\
\hline & & & {$[-2.78]$} & {$[-4.06]$} & {$[-7.25]$} & [9.49] & {$[-8.93]$} & {$[0.60]$} \\
\hline \multirow[t]{2}{*}{ Constant } & $-3.679^{* * *}$ & $5.298^{* * *}$ & $11.773^{* * *}$ & $2.675^{* * *}$ & $10.147^{* * *}$ & $11.574^{* * *}$ & $11.778^{* * *}$ & $1.339^{* *}$ \\
\hline & {$[-3.13]$} & {$[6.78]$} & [19.41] & {$[2.79]$} & {$[9.58]$} & {$[17.05]$} & {$[8.96]$} & {$[2.04]$} \\
\hline Arellano-Bond, AR(1) & N/A & N/A & N/A & $\mathrm{N} / \mathrm{A}$ & N/A & N/A & $\mathrm{N} / \mathrm{A}$ & 0.000 \\
\hline Arellano-Bond, AR(2) & N/A & N/A & N/A & N/A & N/A & N/A & N/A & 0.418 \\
\hline Number of instruments & $\mathrm{N} / \mathrm{A}$ & N/A & N/A & $\mathrm{N} / \mathrm{A}$ & N/A & $\mathrm{N} / \mathrm{A}$ & $\mathrm{N} / \mathrm{A}$ & 33 \\
\hline Wald statistics, $p$-value & N/A & N/A & N/A & $\mathrm{N} / \mathrm{A}$ & $\mathrm{N} / \mathrm{A}$ & $\mathrm{N} / \mathrm{A}$ & N/A & 0.000 \\
\hline Sargan test, $\mathrm{p}$-value & $\mathrm{N} / \mathrm{A}$ & N/A & N/A & $\mathrm{N} / \mathrm{A}$ & $\mathrm{N} / \mathrm{A}$ & N/A & $\mathrm{N} / \mathrm{A}$ & 0.363 \\
\hline Hansen test, p-value & N/A & N/A & $\mathrm{N} / \mathrm{A}$ & N/A & N/A & N/A & N/A & 0.433 \\
\hline Time FE & No & Yes & Yes & No & Yes & Yes & Yes & Yes \\
\hline Exporter FE & No & No & No & Yes & Yes & No & Yes & No \\
\hline Importer FE & No & No & No & Yes & Yes & No & Yes & No \\
\hline Country-pair FE & No & No & No & No & No & Yes & Yes & No \\
\hline Observations & 1,938 & 1,938 & 1,938 & 1,938 & 1,938 & 1,938 & 1,938 & 2,101 \\
\hline R-squared & 0.524 & 0.803 & 0.875 & 0.978 & 0.978 & 0.724 & 0.845 & \\
\hline Number of groups & 213 & 213 & 213 & 213 & 213 & 213 & 213 & 223 \\
\hline
\end{tabular}

Notes: Dependent variable is log bilateral import flow from SEE-5 and EU-NMS-10 countries to OECD-20 countries. Z-statistics in brackets, ${ }^{* * *},{ }^{* *}$ and ${ }^{*}$ indicate significance of coefficients at 1, 5 and 10 per cent, respectively. Column (8): Internal instruments are used for endogenous variables (lagged dependent variable, bilateral FDI stock, and openness). Lag limits are 2/3 for the lagged dependent variable and 4/6 for endogenous regressors. The collapse option is always used. Year dummies are included but not shown. N/A denotes not applicable result.

Source: Author's calculation 
